\title{
Determinants of Company Value in the Indonesia Stock Exchange-Listed Consumer Good Industry, 2017-2020
}

\author{
Ni Wayan Ratna Sari ${ }^{1}$ Nadia Salsabila ${ }^{2, *}$ Ni Made Swandewi Saraswati ${ }^{2}$ Kadek \\ Cipta Dharmayani ${ }^{2}$ Putu Panji Krisna Pradnyana ${ }^{2}$ Ni Kadek Novi Widyantari Oka ${ }^{1}$
}

\author{
${ }^{1}$ Department of Economics and Accounting, Universitas Pendidikan Ganesha, Singaraja, Indonesia \\ ${ }^{2}$ Department of Management, Universitas Pendidikan Ganesha, Singaraja, Indonesia \\ ${ }^{*}$ Corresponding author. Email: nadia.salsabila@undiksha.ac.id
}

\begin{abstract}
One of the objectives of establishing a company is to be able to increase the value of the company. The study aims to determine the effect of collateralizable assets, research and development and sales growth on firm value. The population in this study was all consumer goods industry companies listed in Indonesia Stock Exchange (IDX) during 2017-2020 which amounted to 66 companies. The sampling technique in this study used a purposive sampling method, with a sample of 56 samples (14 companies with 4 years of observation). The data collection method used the documentation method. The data was processed using SPSS version 25.0. The result of the study found that collateralizable assets, research and development had a partially positive and significant effect on the firm value, while sales growth had no effect on the firm value.
\end{abstract}

Keywords: Collateralizable assets, Firm value, Research and development, Sales growth.

\section{INTRODUCTION}

The capital market is a marketplace for long-term trading of financial products such as debt securities (bonds), equity securities (stocks), mutual funds, and derivative instruments issued by governments, public authorities, and private parties. The capital market is utilized to facilitate the selling of funds through a single government-run entity, the Indonesia Stock Exchange. Securities of companies that have gone public or have been listed on the Indonesia Stock Exchange can be purchased and sold [1]. Indonesia's capital market continues to expand at a tremendous speed. This is demonstrated by the fact that the capital market attracts a rising number of investors each year (Table 1).

Table 1. Data on the number of capital market investors

\begin{tabular}{|c|c|c|}
\hline Year & Amount & Increase \\
\hline 2017 & 1.122 .668 & $25,56 \%$ \\
\hline 2018 & 1.619 .372 & $44,24 \%$ \\
\hline 2019 & 2.484 .354 & $53,41 \%$ \\
\hline 2020 & 3.022 .366 & $21,66 \%$ \\
\hline
\end{tabular}

The capital market plays a vital role in the Indonesian economy, as the economy evolves with the times. A capital market is a financial centre in a modern economy. The modern economy cannot function without a capital market that is globally competitive [2]. Additionally, the capital market is critical because it has six tasks, the first of which is to serve as a source of corporate finance or a mechanism for businesses to raise money from investors. The second is for the income distribution tool, which is determined by the number of shares acquired and provides the company with dividends or profit sharing. Thirdly, as a way of expanding a business's manufacturing capacity, and fourthly, as a means of generating personnel, because the existence of a capital market is synonymous with the creation and growth of industry. Fifth, this occurs as a technique of generating state revenue since when dividends are issued to shareholders, the state government collects a tax levy. And the sixth is for indicators of the country's economy, as increasing activities and volumes of sales or purchases in the capital market will have an effect on an entity's ability 
to conduct commercial activities properly [3]. Along with maximizing profits, an entity's objectives include maximizing wealth for investors and maximizing the worth of the entity.

Company value is the market value of all financial assets possessed by the corporation, which must be paid by prospective buyers when the entity is sold, as indicated by the entity's share price. To simplify, the company's value can alternatively be defined as the investors' or general public's perception of the entity as reflected in the firm's share price [4]. According to Jumiari \& Julianto [5], firm value is a measure of an entity's health in a broader sense. There is an important factor that explains why the value of the business is critical; as the value of the business improves, the level of prosperity for the shareholders increases as well. The company's value is critical since it reflects the entity's performance and can be used to characterize the entity's current state and impact investors' perceptions of the company. Additionally, according to Noviani et al. [6], the company's value can give investors the greatest level of comfort when the entity's share price increases. The more comfortable shareholders are, the greater the share price. With a strong firm value, investors will be more interested in investing in the business [7]

Increasing the value of the company requires attention not only from the company or investors, but also from the creditors (lenders). When the creditor makes a loan to the company, he will almost certainly demand collateral in the form of assets owned by the company [8]. This has a lot to do with signalling theory. Signalling theory is a signal or guide given by management to investors about the company's performance and management's perspective on the company's future prospects. Investors will be able to see the company's prospects based on the performance submitted by the company's management. Investors will be able to pay attention to entities with high or low company values based on this signal [9]. According to signal theory, the main factor influencing the company's value is collateralizable assets.

One of the factors that can affect firm value is collateralizable assets. because if the number of assets continues to grow, it can be used as collateral by the company to creditors, indicating that the company has the maximum ability to repay its creditors' loans, and thus it can be explained that the entity has a good credit system will sway shareholders' desire to invest in the entity because investors can assess the entity's low investment risk. When the number of investors grows, they will be able to maximize the company's value. With this positive signal, potential investors will be interested in investing in the company in order to maximize the company's value. Entities with large collateralizable assets will be able to grow and develop more quickly than other businesses. Collateralizable assets, in part, have a positive and significant impact on firm value.

Table 2. Data on collateralizable assets of consumer goods industry companies

\begin{tabular}{|l|c|c|c|}
\hline \multirow{2}{*}{\multicolumn{1}{c|}{ Name }} & \multicolumn{3}{|c|}{ Year } \\
\cline { 2 - 4 } & 2017 & 2018 & 2019 \\
\hline IIKP & $31,25 \%$ & $30,54 \%$ & $21,79 \%$ \\
\hline UNVR & $55,12 \%$ & $54,43 \%$ & $51,89 \%$ \\
\hline GGRM & $32,06 \%$ & $32,93 \%$ & $32,26 \%$ \\
\hline INDF & $44,67 \%$ & $43,90 \%$ & $44,77 \%$ \\
\hline HMSP & $15,97 \%$ & $15,63 \%$ & $14,33 \%$ \\
\hline ICBP & $25,68 \%$ & $31,25 \%$ & $29,30 \%$ \\
\hline WOOD & $43,71 \%$ & $42,12 \%$ & $42,84 \%$ \\
\hline KLBF & $32,15 \%$ & $34,45 \%$ & $37,83 \%$ \\
\hline KAEF & $28,52 \%$ & $29,26 \%$ & $59,56 \%$ \\
\hline HOKI & $29,42 \%$ & $34,71 \%$ & $41,70 \%$ \\
\hline
\end{tabular}

This means that when the entity owns highly collateralizable assets, it will be able to increase the value of the entity itself [1]. Researchers are interested in using this variable in their research because the collateralizable assets of ten companies in the consumer goods industry sector show inconsistency year after year. Most businesses have collateralizable assets that fluctuate year after year, whereas good collateralizable assets increase year after year.

With the growth of a science-based economy, an entity's welfare will be determined by its ability to generate change and capitalize on existing knowledge. When it comes to managing entities, science and technology play a critical role. As a result, businesses must be able to adapt their products in order to survive and compete with other businesses as economic and commercial challenges evolve. This is closely related to the theory of signalling.

Signalling theory is a signal or guide provided by management to investors regarding the company's performance and management's perspective on the company's future prospects. This way, investors can determine the company's prospects based on the performance reported by the company's management. Investors will be able to identify organizations with high or low company values based on this signal [9]. Another aspect that contributes to business value, according to signal theory, is research and development. According to Sugiyono [10], research and development are activities conducted by organizations with the goal of creating new products and processes, modifying current ones, and acquiring new information that will benefit future generations. In businesses, research and development are critical. of an entity in terms of developing new products that the market requires.

Research and development activities, according to Zhu \& Huang [11], will have an effect on business value. Because organizations that engage in research and development will be able to produce more unique goods that are responsive to market needs and technical 
advancements than entities that do not engage in research and development. According to Muis [12], research and development have a major impact on a company's worth. However, [13] explains that research and development have no effect on the company's worth. This indicates that by conducting research and development on its products, the corporation will be able to raise the company's worth. The author is interested in conducting research on this variable because only 14 of the 66 consumer products industrial sector companies listed on the Indonesia Stock Exchange have research and development costs. This demonstrates that there are still very few organizations who generate product advancements on a yearly basis. Whereas product innovation is critical for businesses to demonstrate their competitive advantages.

Businesses must continue to grow in order to raise their worth; this is also related to signalling theory. Signalling theory is a signal or guide provided by management to investors regarding the company's performance and management's perspective on the company's future prospects. This way, investors can determine the company's prospects based on the performance reported by the company's management. Investors will be able to identify organizations with high or low company values based on this signal (Brigham \& Houston, 2014). According to signal theory, the final aspect that might affect firm value is sales growth.

Sales is an agreement between two parties, the seller and the buyer, in which the seller's rights to the products are transferred to the buyer in exchange for the buyer granting the seller rights in the form of money [14]. According to [15], sales growth refers to the annual increase or decrease in the quantity of sales. Significant sales growth can help optimize a business's income and profits since large firm earnings can be utilized to pique shareholders' interest in investing in the entity. As a result, demand for shares increases, which can have an effect on share prices. Profitability will also increase as the entity's share price rises. Increased profits enable the company's worth to grow [16].

Investors will use sales growth to determine the company's value. As a result, further sales growth will serve as a positive indication for the company in terms of maximizing its worth. As a result, revenue growth is critical for the organization [17]. According to [18], sales growth had a favourable but minor effect on firm value. However, as indicated by [8], sales increase has no effect on the firm's worth. This indicates that with strong sales growth, the company's value will improve. Additionally, researchers are interested in examining the consumer goods industry sector from 2017 to 2020, as the consumer goods industry sector decreased by 19.31 percent in November 2019 and was recorded as the sector with the lowest index in November 2019. This was due to a decline in consumer spending as reported in the Bank Indonesia (BI) Retail Sales Survey (SPE) September 2019.

Collateralizable assets are the assets that can be used as security for creditors [8]. Collateralizable assets are one of the elements that can affect a company's worth. Because highly collateralized assets can help resolve issues between investors and creditors, they can also serve as a favourable signal to other shareholders encouraging them to participate in the organization. With this good indication, potential investors will be interested in participating in the business in order to help it grow in value. Businesses with collateralizable assets and access to funding will be able to expand and develop more rapidly than other businesses (Biggs, 2006). This means that the business's large collateralizable assets will represent the fact that the entity has a substantial amount of assets to pledge to creditors, hence increasing the company's worth. According to a study conducted by [1], partially collateralized assets have a beneficial effect on business value. As a result of this explanation, the following hypotheses were developed for this study:

\section{$\mathrm{H}_{1}$ : Collateralizable Assets increase business worth.}

Research and development is a process that an organization undertakes with the goal of creating new products, goods, and processes, or enhancing existing ones, as well as acquiring new information that will help the organization in the future. Research and development on entities is critical in a factory's effort to create new goods required by the market [10]. According to [11], research and development activities have an impact on a company's worth. Because organizations that do research and development activities will be able to introduce more innovative/upto-date products in response to market demands and technical advancements than entities that do not conduct research and development operations.

With creative items, it will undoubtedly attract investors, allowing it to boost the company's value. This means that the company should always do research and development on its products in order to continue to innovate and, through product innovation, boost the company's value. According to research conducted by [19], research and development have a favorable and significant effect on corporate value, and [20] agrees. As a result of this explanation, the following hypotheses were developed for this study:

$\mathrm{H}_{2}$ : Research and development contribute to a firm's value.

Annual sales growth refers to the increase or reduction in the number of sales [15]. Increased sales can boost an entity's revenue and profits because increased earnings will pique shareholders' interest in investing in the entity. As a result, demand for shares will increase, affecting the increase in share prices [21]. 
With a large profit margin, the company will be able to represent its strong marketing performance and experience in competing in the capital market. Businesses that experience significant sales growth will inherently have a higher corporate value. This means that companies with strong sales growth or that are constantly rising will be able to demonstrate that their income is constantly increasing and reflecting the company's success, so enhancing the company's value. According to the results of research conducted by [18], sales growth had a positive and insignificant influence on company value, but also had a significant effect on firm value. As a result of this explanation, the following hypotheses were developed for this study:

\section{$\mathrm{H}_{3}$ : Sales Growth Contributes to the Company's Value}

According to the description above and past research, it demonstrates inconsistent results for the factors investigated, prompting the authors to conduct re-testing on these variables. As a result, the authors are interested in conducting a study named "Determinants of Firm Value in the Consumer Goods Industrial Sector Listed on the Indonesian Stock Exchange in 20172020." First determine whether collateralizable assets have an influence on firm value, secondly to determine whether research and development have an effect on firm value, and thirdly to determine whether sales growth has an effect on firm value.

\section{METHOD}

This study examined the industrial sector for consumer goods that were listed on the Indonesian Stock Exchange between 2017 and 2020. This is a causal quantitative study. Causal quantitative research is any type of research that can provide an overview of generalizations or explanations for the relationship between cause and effect on two variables in the context of multiple additional factors [10]. The research subjects were enterprises in the industrial sector producing consumer goods that were listed on the IDX between 2017 and 2020. The collateralizable assets, research and development, sales growth, and corporate worth are the subjects of the research.

The population for this study is composed of all entities in the industrial sector for consumer products whose data was registered on the IDX between 2017 and 2020, totalling 66 firms. Purposive sampling is the sample technique used. According to the parameters employed, a sample of 14 firms was collected. This figure is multiplied by the observation year, which is four years, yielding a total of 56 samples. The data for this study is derived from secondary sources, specifically financial records provided by an industrial sector company for consumer items listed on the IDX between 2017 and 2020, which can be accessed via Bursa Efek Indonesia.

\section{RESULTS \& DISCUSSION}

Prior to testing hypotheses, the data are evaluated for classical assumptions in order to determine whether the data conditions are normal or not. The normality test is used to assess whether the data distribution is normal. The significant value is found as $0.067>0.05$. This demonstrates that the data's results are regularly distributed. Multilinearity analysis was used to determine whether or not there was a correlation between the study's independent variables. The tolerance value is found more than 0.10 and the VIF value is 10 , it can be stated that this regression model does not exhibit multicollinearity.

Heteroscedasticity testing is used to determine whether a regression model has a variance inequality. The value of sig. (2-tailed) is found greater than 0.05. This shows that there is no heteroscedasticity in this regression model. Autocorrelation testing is used to detect whether a preceding time period contained a test error. It is found that $\mathrm{du}<\mathrm{d}<4$-du. This indicates that there is no autocorrelation in this regression model.

Multiple linear regression analysis is used to determine the direction of the relationship between the independent and dependent variables, as well as whether the relationship is positive or negative. The output of the independent variable coefficient is depicted in table 3 . On the basis of Table 3, the following steps can be taken to create the regression equation.

$\mathrm{Y}=0.039+0.041 \mathrm{X}_{1}+37.606 \mathrm{X}_{2}-0.013 \mathrm{X}_{3}+\mathrm{e}$

The equation indicates that the constant value in the regression equation is 0.039 ; hence, if the independent variable is assumed to be constant $(X=0)$, the dependent variable is also 0.039 . The $\mathrm{T}$ statistical test is used to determine whether the independent variables have a partial or individual effect on the dependent variable. it is known that the $\mathrm{t}$-count values for $\mathrm{X} 1$ and $\mathrm{X} 2$ are more than the t-table values. This implies that the independent variable can have an effect on the dependent variable on its own. The value of sig 0.05 supports this conclusion. However, the value of $\mathrm{t}$-count $\mathrm{t}$-table is X3 for X3. This signifies that the independent variable has no effect on the dependent variable on its own. The fact that sig $>0.05$ supports this conclusion.

The coefficient of determination (R2) test is used to determine the independent variable's percentage influence on the dependent variable. The value of Adjusted R Square is 0.201. This suggests that the independent variable has a 20.1 percent influence on the dependent variable, whereas the remaining 79.9 percent is influenced by factors not mentioned in this research. 
Table 3. Regression analysis result

\begin{tabular}{|l|c|c|c|c|}
\hline \multicolumn{1}{|c|}{ Variable } & Coefficient & t-table & t-count & Sig. \\
\hline Constant & 0,039 & & & \\
\hline Collateralizable Assets & 0,041 & 1,67469 & 3,197 & 0,002 \\
\hline Research and Development & 37,606 & 1,67469 & 2,262 & 0,028 \\
\hline Sales Growth & $-0,013$ & 1,67469 & $-0,999$ & 0,344 \\
\hline
\end{tabular}

According to the findings of the multiple linear regression analysis, the value of t-count (3.197) $>$ t-table (1.67469) with a p-value (0.002) alpha () 0.05 suggests that collateralizable assets have a positive and significant effect on company value. This demonstrates that the company's collateral for creditors is expanding, the company is able to repay its creditors' loans, and so the company's credit system is in good condition. Companies with a strong credit system will be able to attract shareholders' interest in investing in the organization because investors will perceive the company as having a low investment risk. The more investors who invest in a business, the more valuable the business becomes. The findings of this study corroborate the idea advanced by [22], which states that the more assets a firm owns to use as collateral against creditors, the less interest conflicts occur between owners and creditors, hence increasing the company's value. The findings of this study corroborate those of [1], who discovered that collateralizable assets have a favorable and significant effect on business value.

According to the research findings from multiple linear regression analysis, the t-count value $(2.262)>$ the $t$-table value (1.67469) with a p-value $(0.028)$ alpha () 0.05 suggests that research and development has a positive and substantial effect on company value. This demonstrates that companies that are always innovating on existing items or developing new products have more inventive products and can compete with the products of other companies. This can increase public demand for the company's products, hence increasing the company's value. This research supports the notion advanced by [11] that research and development have an effect on corporate value. Because businesses that do research and development activities will be able to produce more innovative products that are responsive to market needs and evolving technology than businesses that do not conduct research and development operations. With unique items, the company will undoubtedly attract investors, which will serve as a positive indicator for increasing the company's value. The findings of this study corroborate those of [19], who discovered that research and development had a favourable and significant effect on business value.

According to the results of multiple linear regression analysis, t-count $(-0.999)>\mathrm{t}$-table $(1.67469)$ with $\mathrm{p}$ value $(0.334)>$ alpha () 0.05 , indicating that sales growth has no effect on firm value. This demonstrates that the rise or decrease in sales at a consumer goods industry sector company between 2017 and 2020 has no effect on the company's worth, as rising expenses have resulted in a decline in profits despite increased sales, which has an effect on the stock price. This study demonstrates that as sales improve, stock prices do not follow suit, despite the fact that stock prices are a critical component in increasing firm value. As a result, investors cannot rely on sales growth as a factor in their investment decisions. This research contradicts the theory advanced by [21], which states that high sales growth can increase a company's revenues or profits because high profits can serve as a signal to investors to become interested in investing in the company. shares demanded will also increase, resulting in an increase in stock prices. The findings of the researchers are similarly consistent with those of [23], who discovered that growth from sales had no effect on firm value.

\section{CONCLUSION}

On the basis of the researcher's data collection and analysis, it can be stated that collateralizable assets have a positive and significant impact on the value of firms in the industrial sector for consumer goods listed on the Indonesian Stock Exchange between 2017 and 2020. The increased firm value can be attributed to the high value of assets pledged as collateral to creditors by consumer goods industry sector entities listed on the IDX from 2017 to 2020. Research and development have a major beneficial effect on the value of a business. The higher the company's valuation, the more significant the impact of product innovations made by consumer goods industrial sector companies listed on the IDX in 2017-2020. Growth in sales has no effect on the firm's worth. The increased firm value is not due to an increase or decrease in the sales growth of consumer goods industrial sector companies listed on the IDX during the period 2017-2020.

According to the conclusions and research findings, this study includes limitations that can be used as a basis for future researchers to better. Researchers make several recommendations, including the following: (1) For the consumer goods industry sector, companies are expected to increase collateralizable assets that can be used as credit guarantees to ensure that investors respond positively to the need for funds, as well as increasing research and development to ensure that companies can continue to grow, and the company must pay closer attention to the level of company sales. Additionally, additional research is expected to develop 
from this research by including additional variables such as liquidity variables in order to determine whether a company's ability to repay current debts using current assets owned by the company has an effect on the increase or decrease in the company's value. in the consumer products sector.

\section{REFERENCES}

[1] A. W. Zulkarnain, "Pengaruh Free Cash Flow, Kepemilikan Manajerial Dan Collateralizable Assets Terhadap Nilai Perusahaan Pada Perusahaan Sektor Industri Barang Konsumsi Yang Terdaftar Di BEI Tahun 2011-2015," J. Chem. Inf. Model., vol. 53(9), pp. 1689-1699, 2017.

[2] OJK, “OJK," 2016. .

[3] F. Muklis, "Perkembangan Dan Tantangan Pasar Modal Indonesia," Al Masraf (Jurnal Lemb. Keuang. Dan Perbankan), vol. 1(1), pp. 1-12, 2016.

[4] J. A. Kweon, Manajemen Keuangan. Jakarta: PT. Macanan Jaya Cemerlang, 2008.

[5] N. K. V Jumiari and I. P. Julianto, "Pengaruh Intellectual Capital, Kinerja Keuangan, dan Kebijakan Keuangan Terhadap Nilai perusahaan," vol. 10(3), p. 48, 2017.

[6] L. P. Noviani, I. P. G. Diatmika, and N. P. Yasa, "Pengaruh Tax Avoidance Terhadap Nilai Perusahaan Dengan Transparansi Sebagai Variabel Pemoderasi," E- J. S1 Ak Univ. Pendidik. Ganesha, vol. 2(1), 2017.

[7] S. Hermuningsih, "Pengaruh Profitabilitas, Size Terhadap Nilai Perusahaan Dengan Struktur Modal Sebagai Variabel Intervening," J. Siasat Bisnis, vol. 16(2), pp. 232-242, 2012, doi: https://doi.org/10.20885/jsb.vol16.iss2.art8.

[8] M. R. A. Helmina and R. Hidayah, "Pengaruh Institusional Ownership, Collateralizable Assets, Debt to Total Assets, Firm Size Terhadap Dividend Payout Ratio," J. Ilm. Ekon. Bisnis, vol. 3(1), pp. 24-32, 2017, doi: https://ejournal.stiepancasetia.ac.id/jieb/article/v iew/49.

[9] E. F. Brigham and J. F. Houston, Fundamentals of Financial Management 15 Edition, 15th ed. Boston: Cengage Learning, 2019.

[10] Sugiyono, Metode Penelitian Kombinasi (Mix Methoders). Alfabeta, 2013.

[11] Z. Zhu and F. Huang, "The Effect of R\&D Investment on Firms Financial Performance: Evidence from the Chinese Listed IT Firm," Mod. Econ., vol. 3(2), 2012.

[12] R. M. Muis, "Pengaruh Corporate Social
Responsibility (Csr), Tipe Industri, Dan Research And Development (R\&D) Terhadap Nilai Perusahaan (Studi Pada Perusahaan Sektor Non Keuangan Yang Terdaftar Di Bursa Efek Indonesia Tahun 2014-2018)," Bandar, 2019.

[13] R. S. Pratama, "Pengaruh product market competition, hedging, research and development, dan marketing terhadap nilai perusahaan (Studi Empiris pada Perusahaan Manufaktur," Repository.Uinjkt.Ac.Id, 2020, doi:

http://repository.uinjkt.ac.id/dspace/handle/1234 $56789 / 51470$.

[14] I. K. S. Arta, M. A. Wahyuni, I. G. Agus, and Yudantara, "PENGARUH PERPUTARAN PERSEDIAAN, PERTUMBUHAN PENJUALAN, TINGKAT HPP, DAN INFLASI TERHADAP PROFITABILITAS PADA PT. PERIKANAN NUSANTARA (PERSERO) CABANG BENOA TAHUN 2016-2018," vol. 11(3), 2020.

[15] A. Sartono, Manajemen Keuangan Teori dan Aplikasi, Edisi Keempat. Yogyakarta: BPFE, 2010.

[16] M. Waskito and S. Faizah, "PENGARUH RETURN ON EQUITY (ROE) DAN PERTUMBUHAN PENJUALAN TERHADAP HARGA SAHAM PERUSAHAAN," vol. 3(1), pp. 30-43, 2021.

[17] T. K. R. Lingga, "Pengaruh Pertumbuhan Penjualan, Profitabilitas, Struktur Modal, Dan Struktur Aktiva Terhadap Nilai Perusahaan Pada Perusahaan Manufaktur Yang Terdaftar Di Bursa Efek Indonesia. Strata-1 M(Fakultas Ekonomi Dan Bisnis)," Universitas Sumatera Utara, 2019.

[18] I. G. N. S. Wijaya, "Pengaruh Pertumbuhan Penjualan Terhadap Nilai Perusahaan Dengan Struktur Modal Sebagai Variabel Intervening," J. Ilmu Manaj., vol. 9(2), 2019, doi: http://scioteca.caf.com/bitstream/handle/123456 789/1091/RED2017-Eng-

8ene.pdf? sequence $=12$ \&isAllowed=y\%0Ahttp:/ /dx.doi.org/10.1016/j.regsciurbeco.2008.06.005 \%0Ahttps://www.researchgate.net/publication/3 05320484_SISTEM_PEMBETUNGAN_TERP USAT_STRATEGI_MELESTARI.

[19] A. P. Kurniawan and I. M. Mertha, "Kinerja Keuangan Sebagai Pemediasi Pengaruh Intensitas Research and Development Dan Aset Tidak Berwujud Pada Nilai Perusahaan," EJurnal Akunt. Univ. Udayana, vol. 14(1), pp. 723-750, 2016.

[20] S. C. M. Mahdita, "Pengaruh Intensitas Research and Development Dan Kinerja Perusahaan Terhadap Nilai Perusahaan," $J$. 
Akunt. AKUNESA, vol. 5(1), 2016.

[21] M. Waskito and S. Faizah, "PENGARUH RETURN ON EQUITY (ROE) DAN PERTUMBUHAN PENJUALAN TERHADAP HARGA SAHAM PERUSAHAAN," vol. 3(1), pp. 30-43, 2021.

[22] S. Titman and R. Wessels, "The Determinants of Capital Structure Choice," J. Finance, 1988.

[23] L. N. A. Herawati, "Pengaruh Ukuran Perusahaan, Leverage, Pertumbuhan Penjualan Dan Profitabilitas Terhadap Nilai Perusahaan Pada Perusahaan Yang Terdaftar Dalam Indeks LQ45," Akunt. (Sekolah Tinggi Ilmu Ekon., 2017. 